\title{
PENGARUH PROMOSI FACEBOOK, TWITTER, DAN INSTAGRAM TERHADAP KEPUTUSAN WISATAWAN KE PANTAI PANDAWA BALI
}

\author{
Topan Raditya ${ }^{1}$, I Wayan Suardana ${ }^{2}$, Putu Agus Wikanatha Sagita ${ }^{3}$ \\ 1Email: toraditya@gmail.com \\ Program Studi Industri Perjalanan Wisata, Fakultas Pariwisata, Universitas Udayana \\ ${ }^{2}$ Email: suar.dana@yahoo.co.id \\ Program Studi Industri Perjalanan Wisata, Fakultas Pariwisata, Universitas Udayana \\ ${ }^{3}$ Email: wika.fpar@gmail.com \\ Program Studi Industri Perjalanan Wisata, Fakultas Pariwisata, Universitas Udayana
}

\begin{abstract}
This research intended to find out: (1) How is the influence of promotion on social media facebook, twitter and instagram on the image of the Pandawa beach?, (2) How does the promotion on social media Facebook, Twitter and Instagram influence the decision to visit tourists to the Pandawa beach? (3) What is the effect of the image of the Pandawa beach in touristic decisions?, The results showed (1) Social Media Promotion variable (X) has a direct influence on the Image (Y1) because it has a probability value $(0,554) \leq 0.05$ which means there is a significant positive effect, (2) Social Media Promotion variable ( X) has a positive influence on Visiting Decision (Y2) because it has a probability value $(0,207) \leq 0.05$ which means there is a significant positive effect. (3) Image variable (Y1) has a positive influence on Visiting Decision (Y2) because it has probability value $(0,516) \leq$ 0.05 which means there is a significant positive effect. Based on the conclusions stated above, several suggestions were given and were expected to provide benefits to the aid providers of the management of the Bali Pandawa beach. It is expected that the management to always maintain and try to improve the positive image of the Pandawa beach that has been embedded in the minds of the public and it is also hoped that the management will more aggressively promote tourist attractions on the Pandawa beach through social media, because promotion through social media is believed to be the most effective way to introduce beauty and the uniqueness of the Pandawa beach to the wider community.
\end{abstract}

Abstrak: Penelitian ini bertujuan untuk mengetahui: (1) Bagaimanakah Pengaruh Promosi di Media Sosial Facebook, Twitter dan Instagram Terhadap Citra Pantai Pandawa?, (2) Bagaimanakah Pengaruh Promosi di Media Sosial Facebook, Twitter Dan Instagram Terhadap Keputusan Berkunjung Wisatawan ke Pantai Pandawa?, (3) Bagaimanakah Pengaruh Citra Pantai Pandawa Terhadap Keputusan Berkunjung Wisatawan?, Teknik analisis data dengan menggunakan Partial Least Square (PLS). Hasil penelitian menunjukkan (1) Promosi media sosial (X) memiliki pengaruh secara langsung terhadap citra (Y1) karena memiliki nilai probabilitas $(0,554) \leq 0,05$ yang berarti ada pengaruh positif yang signifikan., (2) Promosi media sosial (X) memiliki pengaruh yang positif terhadap keputusan berkunjung (Y2) karena memiliki nilai probabilitas $(0,207) \leq 0,05$ yang berarti ada pengaruh positif., (3) Citra (Y1) memiliki pengaruh positif terhadap keputusan berkunjung (Y2) karena memiliki nilai probabilitas $(0,516) \leq 0,05$ yang berarti ada pengaruh positif yang signifikan. Berdasarkan dari simpulan yang dikemukakan seperti diatas, diberikan beberapa saran dan diharapkan dapat memberikan manfaat bagi pembaca maupun pihak pengelola pantai Pandawa Bali. Diharapkan pihak pengelola untuk selalu menjaga dan berusaha meningkatkan citra positif pantai Pandawa yang sudah tertanam di benak masyarakat dan diharapkan juga pihak pengelola lebih gencar mempromosikan atraksi wisata di pantai Pandawa melalui media sosial, karena promosi melalui media sosial diyakini sebagai cara paling efektif untuk memperkenalkan keindahan dan keunikan pantai Pandawa kepada masyarakat luas.

Keywords: social media promotion, image, visiting decision. 


\section{PENDAHULUAN}

Bali merupakan daerah tujuan utama pariwisata di Indonesia dan juga sebagai salah satu daerah tujuan wisata terkemuka di dunia. Reputasi Bali sebagai tujuan wisata yang terkenal telah tertanam dalam benak banyak orang di seluruh dunia. Bali terkenal sebagai pulau yang indah dengan pegunungan, pantai, pura dan sawahnya yang bertingkat-tingkat. Wisatawan yang berkunjung ke Pulau Bali tidak akan pernah merasa bosan dan jenuh, karena selalu menemukan suasana baru serta atraksi yang unik dan menarik untuk dinikmati. Jumlah wisatawan yang berkunjung ke Bali rata-rata meningkat setiap tahunnya, meskipun dari jumlah meningkat tetapi secara persentase sempat terjadi penurunan. Hal ini disebabkan oleh beberapa faktor yang salah satunya adalah kemajuan pariwisata di luar Bali sehingga menggerus kunjungan wisatawan ke Bali. Meningkatnya jumlah wisatawan yang berkunjung akan memberikan dampak yang positif terhadap perekonomian setempat. Oleh sebab itu peningkatan sektor pariwisata sangat dibutuhkan demi meningkatkan pendapatan masyarakat Bali dan juga menambah devisa negara.

Perkembangan pariwisata Bali saat ini tidak terlepas dari kemajuan teknologi informasi khususnya internet. Tak sedikit wisatawan yang mencari referensi untuk berwisata secara online. Calon wisatawan biasanya sangat terpengaruh oleh foto-foto yang terunggah di internet. Bahkan kebanyakan dari mereka merasa tertarik untuk berkunjung setelah melihat foto maupun testimoni dari pengunjung yang mereka lihat.

Kemajuan teknologi informasi khususnya internet telah mengubah cara manusia dalam berkomunikasi. Kehadiran internet dalam kehidupan manusia memberikan kemudahan bagi masyarakat untuk mengakses informasi yang dibutuhkan. Internet telah menjadi kebutuhan dalam pencarian informasi terkait perencanaan, pengambilan keputusan dan segala kebutuhan pembelinya. Internet saat ini digunakan sebagai media promosi digital, bentuk-bentuk promosi digital dapat melalui website perusahaan, blog, dan media sosial.

Tujuan dari promosi melalui internet adalah untuk membangun citra yang kuat bagi wisatawan dalam rangka menghasilkan daya tarik yang kuat dari sebuah destinasi wisata.
Sebab, ketika wisatawan menilai dan mengevaluasi suatu destinasi, persepsi terhadap destinasi merupakan komponen kunci untuk melakukan kunjungan atau tidak. Oleh karena itu, citra yang positif perlu dikembangkan oleh setiap destinasi, sebab citra positif berarti membantu wisatawan melihat keistimewaan produk suatu destinasi.dan mampu membuat wisatawan merasa terpuaskan sehingga mereka akan tertarik untuk berkunjung.

Media sosial merupakan sebuah media berbasis internet yang memudahkan atau memungkinkan penggunanya dapat dengan mudah berpartisipasi, menciptakan dan berbagi pengalaman serta informasi yang dimilikinya. Jenis-jenis media sosial tersebut seperti facebook, twitter dan instagram.

Media sosial mampu menyebarkan informasi dengan cepat dan daya jangkau yang luar biasa dibandingkan dengan media manapun. Perkembangan media sosial secara tidak langsung membuat arus informasi menjadi begitu cepat diterima oleh masyarakat luas. Promosi melalui media sosial secara tepat dapat menarik wisatawan untuk menggunakan produk mereka.

Kusuma Negara dan Sagita (2018), dalam penelitiannya menyatakan bahwa smartphone tidak hanya sebagai alat teknologi saja, namun telah menjadi alat perjalanan wisata serta kegiatan sosial panggung, kreativitas, dan berbagi pengalaman. Pergeseran dalam tahap perjalanan telah berubah karena smartphone, wisatawan dapat memilih untuk melakukan perjalanan secara online, wisatawan spontan dapat mengubah rencana perjalanan karena kejadian tak terduga, dan berbagi momen perjalanan.

Tidak dapat dipungkiri bahwa pantai merupakan daya tarik utama bagi wisatawan untuk berkunjung ke Bali. Salah satu pantai yang menjadi favorit bagi wisatawan ketika berwisata ke Bali adalah pantai Pandawa. Pantai Pandawa pertama kali dibuka secara resmi pada tanggal 27 Desember 2012 bersamaan dengan diadakannya Pandawa Beach Festival. Pantai ini berlokasi di Bali Selatan, tepatnya di Desa Kutuh, Kecamatan Kuta Selatan, Kabupaten Badung, Bali. Pantai Pandawa adalah salah satu pantai di Bali yang memiliki keindahan pasir putih yang lembut dan airnya yang jernih kebiruan dengan suasana pantai yang tenang. Selain itu pengunjung yang memasuki kawasan pantai 
ini akan disambut oleh pemandangan tebing / bukit kapur yang sangat besar dengan ukiran dan patung pandawa yang sengaja ditempatkan di dinding tebing.

Jumlah kunjungan wisatawan ke pantai Pandawa meningkat setiap tahunnya, hal ini merupakan fakta bahwa pantai Pandawa semakin dikenal oleh masyarakat. Menurut Suardana (2016) Pengembangan destinasi pariwisata memerlukan teknik perencanaan yang baik dan tepat. Teknik pengembangan harus menggabungkan beberapa aspek penunjang kesuksesan pariwisata. Aspekaspek tersebut adalah aspek aksesibilitas (transportasi dan saluran pemasaran), karakteristik infrastruktur pariwisata, tingkat interaksi sosial, keterkaitan/kompatibilitas dengan sektor lain, daya tahan akan dampak pariwisata, tingkat resistensi komunitas lokal, dan seterusnya. Salah satu cara meningkatkan interaksi sosial untuk memperkenalkan pantai Pandawa kepada masyarakat adalah melalui media sosial seperti facebook, twitter dan instagram. Seharusnya para pelaku usaha pariwisata di kawasan Pantai Pandawa Bali mampu memanfaatkannya sebagai sarana promosi supaya informasi dapat tersampaikan dengan efektif dan tepat sasaran sehingga pantai Pandawa akan semakin dikenal dan berkembang.

Menurut Taprial \& Kanwar (2012) media sosial memiliki beberapa keunggulan yang menjadikannya lebih kuat dibandingkan media tradisional yaitu: (1). Accessibility Sosial Media mudah untuk diakses karena memerlukan sedikit atau tidak ada biaya sama sekali dalam penggunaanya. (2). Speed, konten yang dibuat dalam sosial media tersedia bagi semua orang yang berada dalam jaringan, forum, atau komunitas begitu diterbitkan. (3). Interactivity, media sosial dapat menampung dua atau lebih saluran komunikasi. (4). Longevity / Volativity, konten pada sosial media tetap dapat diakses pada waktu yang lama, atau bahkan selamanya. (5) Reach, internet menawarkan jangkauan yang tidak terbatas ke semua konten yang tersedia.

Pada saat ini dapat kita rasakan kemudahan mendapatkan informasi dengan menggunakan media sosial. Begitu juga dengan pantai Pandawa, informasi mengenai pantai Pandawa dapat kita ketahui dengan mudah. Cukup memasukkan nama pantai Pandawa di kolom pencarian, maka akan muncul sangat banyak foto dan ulasan tentang pantai Pandawa. Banyak akun personal ataupun akun official wisata yang memamerkan keindahan pantai Pandawa dan merekomendasikannya untuk dikunjungi. Dengan semakin banyaknya ulasan mengenai pantai Pandawa yang memberikan pendapat positif maka hal tersebut mampu meningkatkan citra pantai Pandawa secara signifikan sehingga jumlah wisatawan yang tertarik untuk berkunjung akan semakin meningkat. Fenomena menarik yang terjadi saat ini, wisatawan sendirilah yang lebih gencar mempromosikan objek wisata pantai Pandawa. Hal ini tidak terlepas dari budaya selfie yang melekat di masyarakat. Semakin banyak foto atau video beserta ulasan tentang atraksi wisata yang ada di pantai Pandawa maka akan semakin menarik minat wisatawan untuk berkunjung. Secara tidak langsung wisatawan juga telah membantu mempromosikan dan meningkakan citra pantai Pandawa sebagai objek wisata unggulan kepada dunia.

Pantai Pandawa merupakan salah satu objek wisata di Bali yang mulai dikenal masyarakat sejak tahun 2013, yang dimana pada periode tersebut juga merupakan masamasa meledaknya penggunaan media sosial seperti facebook, twitter dan instagram. Berdasarkan hal tersebut, peneliti tertarik untuk mengetahui bagaimana pengaruh dari promosi media sosial terhadap kunjungan wisatawan ke pantai Pandawa.

\section{METODE PENELITIAN}

Penelitian ini akan dilakukan di kawasan pantai Pandawa Bali yang terletak di Desa Kutuh, Kuta Selatan. Peneliti memilih pantai Pandawa sebagai objek penelitian karena pantai Pandawa termasuk dari salah satu objek wisata di Bali yang perkembangannya sangat pesat. Hanya dalam kurun waktu kurang dari 5 tahun, pantai Pandawa Bali dari pantai yang kurang dikenal menjadi salah satu daerah tujuan wisata favorit.

Variabel yang digunakan dalam penelitian ini mengadopsi dari hasil penelitian sebelumnya dan juga beberapa konsep dari buku yang terkait dengan pengaruh media sosial terhadap keputusan berkunjung wisatawan. Terdapat 3 variabel yaitu variabel bebas (promosi media sosial), penghubung (citra) dan terikat (keputusan berkunjung). 
Penelitian ini menggunakan dua jenis data. Pertama, data kualitatif berupa gambaran mengenai objek penelitian dan menunjukkan kualitas objek penelitian yang dilakukan yaitu pantai Pandawa. Kedua, Data kuantitatif berupa jumlah kunjungan wisatawan ke Bali, jumlah kunjungan wisatawan ke pantai Pandawa dan data yang diperoleh berdasarkan hasil dari penyebaran kuesioner kepada responden yang berkunjung ke Pantai Pandawa.

Data primer dalam penelitian merupakan data yang diperoleh dari pihak pertama di lokasi penelitian melalui wawancara dengan pihak-pihak yang terkait, berdasarkan pengamatan langsung ataupun dengan cara menyebarkan kuesioner secara langsung di objek penelitian. Data sekunder merupakan data pendukung yang diperoleh dari pihak ketiga seperti hasil penelitian terdahulu, internet, buku-buku, dan teori-teori yang dapat mendukung penelitian ini.

Teknik pengumpulan data yang digunakan dalam penelitian ini menggunakan tiga cara yaitu. (1) Observasi adalah pengamatan langsung pada suatu objek demi mendapatkan informasi-informasi yang dibutuhkan untuk melanjutkan penelitian. Pengamatan dilakukan dengan mengunjungi pantai Pandawa secara langsung dan mencatat berbagai fenomena yang terjadi. Wawancara yaitu teknik pengumpulan data dengan metode wawancara secara langsung kepada informan dengan berpedoman pada daftar pertanyaan yang telah disiapkan sebelumnya. Dalam hal ini wawancara dilakukan kepada pihak pengelola pantai pandawa. (3) Kuesioner merupakan sebuah daftar pertanyaan yang harus diisi oleh orang yang akan diukur (responden). Dengan kuesioner Kita dapat mengetahui keadaan atau data pribadi seseorang, pengalaman atau pengetahuan dan lain-lain yang dimilikinya,

(4) Studi Kepustakaan yaitu teknik pengumpulan data dengan cara mengumpulkan data-data yang diperlukan dari literatur, buku-buku atau referensi lainnya yang memiliki hubungan dengan penelitian ini.

Teknik penentuan sampel, dikarenakan sulitnya mengetahui jumlah pasti wisatawan yang mengetahui tentang pantai Pandawa melalui media sosial maka teknik penentuan sampel yang digunakan adalah teknik non probability sampling, yaitu purposive sampling. Menurut Margono (2004), pemilihan sekelompok subjek dalam purposive sampling didasarkan atas ciri-ciri tertentu yang dipandang mempunyai sangkut paut yang erat dengan ciri-ciri populasi yang sudah diketahui sebelumnya, dengan kata lain unit sampel yang dihubungi disesuaikan dengan kriteria-kriteria tertentu yang diterapkan berdasarkan tujuan penelitian. Teknik purposive sampling pada dasarnya dilakukan sebagai sebuah teknik yang secara sengaja mengambil sampel tertentu yang telah sesuai dan memenuhi segala persyaratan yang dibutuhkan yang meliputi sifat-sifat, karakteristk ciri dan kriteria sampel tertentu. Karakeristik yang dimaksud disini yaitu pengguna media sosial facebook, twitter dan instagram yang mengetahui tentang objek wisata pantai Pandawa Bali.

Menurut Hair dkk dalam Prawira (2010) ukuran sampel yang disarankan antara 100-200 responden. Ferdinand (2014), menyatakan bahwa jumlah sampel minimal adalah 5 kali dari jumlah indikator dalam penelitian, adapun jumlah indikator dalam penelitian ini sebanyak 20. Berdasarkan teori tersebut maka jumlah minimal sampel dalam penelitian ini adalah $20 \times 5=100$ sampel. Penelitian ini menggunakan dua teknik analisis data yaitu melalui uji instrumen dan analisis partial least square. Sehingga diperoleh gambaran yang jelas dan objektif mengenai hubungan antara promosi media sosial terhadap citra dan keputusan berkunjung wisatawan ke pantai Pandawa Bali.

\section{HASIL}

Pantai Pandawa merupakan salah satu destinasi wisata yang dikenal akan pasir putihnya. Pantai Pandawa merupakan salah satu kawasan wisata di Desa Kutuh, Kecamatan Kuta Selatan, Kabupaten Badung, Bali. Untuk menuju ke Pantai Pandawa dibutuhkan perjalanan kurang lebih satu jam dari Bandara Ngurah Rai. Setelah sampai di kawasan Pantai Pandawa, wisatawan akan melewati jalan turunan yang sudah beraspal dan disana terdapat dua tebing yang sangat besar di sekitar pantai ini. Salah satu sisi dari tebing ini dipahat lima patung Pandawa dan Kunti. Keenam patung tersebut disusun secara berurutan dari posisi tertinggi dan diberi penjelasan nama Dewi Kunti, Dharma 
Wangsa, Bima, Arjuna, Nakula, dan Sadewa. Patung tersebut ukurannya cukup besar dan sangat indah jika dilihat dari bawah. Disamping patung tersebut wisatawan juga akan melihat pantai yang begitu indah. Hamparan pasir putih yang bersih serta ombak yang tenang dan bebas dari polusi udara bisa dinikmati di sepanjang Pantai Pandawa. Sebelum dibuka secara resmi pada tanggal 27 Desember 2012, pantai Pandawa dulunya digunakan sebagai tempat untuk budidaya rumput laut oleh penduduk setempat. Melihat potensi yang dimiliki pantai Pandawa, akhirnya Tim Penataan Desa pun mulai membangun infrastuktur. Pembangunan dimulai dari membuka akses jalan raya menuju pantai, penataan dinding-dinding kapur di sekitar pantai dan pembangunan fasilitas umum untuk memberikan kenyamanan bagi pengunjung. Dulunya sebelum pantai Pandawa menjadi populer seperti sekarang ini, para wisatawan lebih sering mengenalnya dengan nama Secret Beach karena memang terletak di balik bukit. Keindahan pantai Pandawa menjadi semakin terkenal di mata dunia setelah adanya akses jalan masuk dengan cara mengeruk bukit. Keberadaan tebing batu kapur yang terbentuk setelah pembuatan jalan terlihat berpadu serasi menampilkan panorama alam yang indah. Selain memiliki panorama alam yang indah, pantai Pandawa juga memiliki berbagai atraksi wisata seperti snorkeling, kano, paralayang dan pertunjukkan seni tari yang menjadikan daya tarik wisata tersendiri untuk dikunjungi wisatawan. Pantai Pandawa terletak di Desa Kutuh, Kecamatan Kuta Selatan, Kabupaten Badung, Bali. Panjang pantai ini sekitar $1 \mathrm{~km}$ yang diapit oleh dua buah tanjung kecil di sebelah kiri dan kanan. Luas tanah yang termasuk dalam wilayah Desa Kutuh adalah seluas 976,800 Ha dengan jumlah penduduk sebanyak 3.781 jiwa (2015). Wilayahnya disebelah utara berbatasan dengan Kelurahan Jimbaran, sebelah timur dengan Kelurahan Benoa, sebelah selatan Samudera Indonesia, dan sebelah barat berbatasan dengan Desa Ungasan. Pantai Pandawa merupakan wilayah dataran tinggi dan masih termasuk dalam daerah iklim tropis dengan curah hujan rata-rata per tahun antara $1000 \mathrm{~mm}-2000 \mathrm{~mm}$, sedangkan suhu udara hariannya berkisar diantara $24^{\circ} \mathrm{C}-32^{\circ} \mathrm{C}$.

\section{Karakteristik Wisatawan}

Berdasarkan hasil dari kuesioner yang telah disebarkan kepada wisatawan yang berjumlah sebanyak 100 responden, maka diketahui bahwa jumlah wisatawan terbanyak yang berkunjung ke Pantai Pandawa adalah usia 22-28 tahun (38\%), jadi dapat disimpulkan bahwa mayoritas pengunjung pantai Pandawa adalah usia milenial. Berdasarkan jenis kelamin diketahui bahwa jumlah wisatawan yang berkunjung ke Pantai Pandawa mayoritas adalah perempuan yakni sebanyak $53 \%$, sedangkan laki-laki berjumlah $47 \%$, sehingga dapat disimpulkan bahwa wisatawan yang berkunjung ke pantai Pandawa pergi secara berpasangan atau berkelompok. Selanjutnya berdasarkan tingkat pendidikan, diketahui bahwa persentase terbesar status pendidikan wisatawan Pantai Pandawa adalah sarjana (57\%) yang berarti bahwa mayoritas status pendidikan dari wisatawan yang berkunjung cukup tinggi yaitu sarjana. Berdasarkan pekerjaan diketahui bahwa sebagian besar wisatawan Pantai Pandawa adalah pelajar (47\%), sehingga dapat disimpulkan bahwa pengunjung pantai Pandawa adalah wisatawan yang masih memiliki banyak waktu luang untuk berlibur. Berdasarkan media sosial yang digunakan diketahui sebagian besar wisatawan yang berkunjung ke Pantai Pandawa menggunakan media sosial Instagram (67\%), maka dapat disimpulkan bahwa wisatawan yang berkunjung mengetahui tentang pantai Pandawa dari Instagram. Yang terakhir berdasarkan frekuensi akses diketahui bahwa sebagian besar wisatawan yang berkunjung ke Pantai Pandawa mengakses akun media sosial mereka sebanyak 10 kali per hari (52\%), yang berarti bahwa mayoritas wisatawan pantai Pandawa adalah orang yang cukup sering mengakses akun media sosial mereka.

\section{Uji Validitas dan Realibilitas}

Validitas adalah suatu standar ukuran yang menunjukkan ketepatan dan kesahihan suatu instrumen. Uji validitas mengarah pada ketepatan interpretasi hasil penggunan prosedur evaluasi sesuai dengan tujuan pengukurannya. Maksud dari uji validitas adalah unuk mengetahui keabsahan menyangkut antara teori konsep dan kenyataan empiris. Suatu kuesioner dikatakan valid jika pertanyaan pada kuesioner tersebut 
mampu untuk mengungkapkan sesuatu yang akan diukur pada penelitian tersebut. Jika nilai $r$ hitung lebih besar dari nilai $r$ Tabel maka item tersebut adalah valid (Riduwan. 2011). Pengujian validitas pada penelitian ini menggunakan SPSS versi 21 sehingga ditemukan hasil nilai koefisien korelasi dari masing-masing variabel $>0,3$ dapat disimpulkan bahwa indikator-indikator variabel pada penelitian ini adalah valid. Sedangkan nilai alpha cronbach dari ketiga variabel pada penelitian ini menunjukkan nilai lebih besar dari 0,6. Dapat disimpulkan bahwa variabel penelitian ini sudah reliabel.

\section{Hasil Analisis Data Partial Least Square}

Partial least square atau yang biasa disingkat PLS adalah jenis analisis statistik yang kegunaannya mirip dengan SEM. Oleh karena mirip SEM maka kerangka dasar dalam PLS yang digunakan adalah berbasis regresi linear. Hasil analisis dari PLS dapat dikategorikan dalam 2 tahapan yaitu Outer Model (Model Pengukuran) dan Inner Model (Model Struktural). Outer Model (Model Pengukuran) dilakukan dengan melihat Convergent validity, Contruct Reliability, dan Discriminant validity.

Menurut Ghozali (2013), suatu indikator dikatakan mempunyai reliabilitas yang baik jika nilai outer loading untuk masing-masing indikator $>0.70$ (penelitian pada bidang yang belum berkembang bisa menggunakan 0.50 - 0.60). Berdasarkan hasil penelitian bahwa semua nilai indikator pada promosi media sosial (X), citra (Y1) dan keputusan berkunjung (Y2) lebih besar dari 0.50 oleh sebab itu dapat dikatakan bahwa semua indikatorindikator tersebut valid. Hal ini sesuai dengan ketentuan seperti yang telah disebutkan diatas.

Evaluasi Inner Model dilakukan dengan menggunakan $R$-square untuk konstruk dependen uji t serta signifikansi dari koefisien parameter jalur struktural. Pengujian terhadap model struktural dilakukan dengan melihat nilai $R$-square yang merupakan uji goodnessfit model. Output Model struktural dilakukan dengan melakukan bootstraping lalu lihat output analisis dari nilai R2 (koefisien determinasi), nilai Q2 (predictive relevance).

Penelitian ini pada dasarnya menggunakan 2 variabel yang dipengaruhi oleh variabel lainnya yaitu variabel Citra (Y1) yang dipengaruhi oleh variabel Promosi Media Sosial (X). Demikian juga dengan variabel Keputusan Berkunjung (Y2) yang dipengaruhi oleh variabel Promosi Media Sosial (X) dan variabel Citra (Y1). Tabel 4.15 menunjukan nilai $\mathrm{R}$-square untuk variabel Kepercayaan diperoleh sebesar 0,307. Nilai $R$ square tersebut menunjukkan bahwa $30,7 \%$ variabel Citra (Y1) dapat dipengaruhi oleh variabel Promosi Media Sosial (X). sedangkan sisanya $69,3 \%$ di pengaruhi oleh variabel lain di luar yang diteliti. Tabel 4.15 menunjukkan nilai $R$-square Kepuasan sebesar 0,427 menunjukkan variabel Keputusan Berkunjung (Y2) dipengaruhi oleh variabel Promosi Media Sosial (X), dan Citra (Y1) sebesar $42,7 \%$ sedangkan sisanya $57,3 \%$ di pengaruhi oleh variabel lain di luar yang diteliti.

\section{Predictive Relevance (Q2)}

Besaran Q2 memiliki nilai dengan rentang $0<\mathrm{Q} 2<1$, dimana semakin mendekati 1 berarti model semakin baik. Besaran Q2 ini setara dengan koefisien determinasi total pada analisis jalur (path analysis). Menurut Jaya dan Sumertajaya (2008) Goodness of Fit Model diukur menggunakan $R$-square variabel laten dependen dengan interpretasi yang sama dengan regresi; $Q$-Square predictive relevance untuk model struktural, mengukur seberapa baik nilai konservasi dihasilkan oleh model dan juga estimasi parameternya.

Berdasarkan hasil penelitian diketahui bahwa nilai Q2 sebesar 0.603, yang berarti besarnya keragaman data dari penelitian yang dapat dijelaskan oleh model struktural yang dirancang adalah sebesar $60,3 \%$, sedangkan sisanya $39,7 \%$ dijelaskan oleh faktor lain diluar model penelitian. Berdasarkan hasil perhitungan ini maka dapat ditarik kesimpulan bahwa model struktural pada penelitian ini cukup baik karena cukup mendekati nilai 1 .

\section{Pengujian Hipotesis Penelitian}

Pada penelitian ini pengujian terhadap sampel dilakukan dengan metode bootstrap. Dengan menggunakan metode pengujian bootstrap diharapkan dapat meminimalkan masalah ketidaknormalan pada data penelitian. Berdasarkan hasil penelitian, 
diperoleh persamaan struktural sebagai berikut:

$\mathrm{Y} 1=0,554 \mathrm{X}$

$Y 2=0,207 X+0,516 Y$

Hasil dari estimasi parameter yang signifikan memberikan informasi yang sangat penting mengenai hubungan antar variabel pada penelitian ini. Dasar pengujian hipotesis menggunakan nilai yang terdapat pada output result for inner weight. Pengujian hipotesis dilakukan dengan melihat nilai probabilitas nya dan t-statistiknya. Untuk nilai probabilitas, nilai p-value dengan alpha 5\% adalah kurang dari 0,05 . Nilai t-Tabel untuk alpha 5\% adalah 1,96. Sehingga kriteria penerimaan Hipotesa adalah ketika t-statistik lebih besar dari t-Tabel.

Berdasarkan hasil analisis, diketahui bahwa nilai variabel promosi media sosial terhadap citra dengan koefisien jalur sebesar 0,554 dan $\mathrm{t}$ statistik sebesar 8,479. nilai tersebut lebih besar dari t Tabel $(1,960)$ atau $p$ $\leq 0,05 \%$. Sehingga Promosi di media sosial facebook, twitter dan instagram berpengaruh positif signifikan terhadap peningkatan Citra pantai Pandawa. Berdasarkan hasil observasi yang dilakukan, ditemukan bahwa foto, ulasan serta pengalaman wisatawan yang sudah berkunjung dan membagikannya di media sosial berperan cukup besar dalam meningkatkan citra positif pantai Pandawa sebagai destinasi wisata yang memiliki pemandangan indah, bersih dan keunikan tersendiri di benak masyarakat. Dari hasil tersebut menunjukkan bahwa hipotesis pertama penelitian ini diterima. Pernyataan ini juga diperkuat oleh hasil penelitian yang dilakukan Sahin dan Sengün (2015), yang menunjukkan bahwa media sosial menjadi semakin penting saat ini, efek ini juga berpengaruh signifikan terhadap pasar pariwisata. Singkatnya, dengan adanya promosi melalui media sosial akan meningkatkan citra positif dari pantai Pandawa secara cukup signifikan karena media sosial mampu menyebarkan informasi secara cepat dan daya jangkau yang lebih luas dari media lainnya.

Nilai variabel promosi media sosial terhadap keputusan berkunjung dengan koefisien jalur sebesar 0,207 dan t statistik sebesar 1,895 . Nilai tersebut lebih kecil dari t Tabel $(1,960)$ atau $p \leq 0,05 \%$. Sehingga promosi di media sosial facebook, twitter dan instagram berpengaruh positif namun tidak signifikan terhadap keputusan berkunjung ke pantai Pandawa. Berdasarkan hasil observasi, ditemukan bahwa dengan terpenuhinya kepuasan wisatawan yang berkunjung akan memberikan dampak yang positif terhadap psikologis sehingga mungkin wisatawan tersebut akan merekomendasikan pantai Pandawa kepada orang-orang disekitarnya. Dari hasil tersebut dapat disimpulkan bahwa hipotesis kedua penelitian ini diterima. Pernyataan ini diperkuat hasil dari penelitian yang dilakukan oleh Živković, Gajić dan Brdar (2014), yang menunjukkan bahwa pemasaran akan banyak terkonsentrasi pada peningkatan hubungan di media sosial dan beradaptasi dengan kebutuhan wisatawan. Pariwisata perlu melibatkan wisatawan dengan melakukan komunikasi secara terpadu dan mendorong mereka untuk berbagi pengalaman indah serta merekomendasikannya. Dengan banyaknya rekomendasi di media sosial tentang pantai Pandawa, maka akan meningkatkan jumlah wisatawan yang berkunjung.

Nilai variabel citra terhadap keputusan berkunjung dengan koefisien jalur sebesar 0,516 dan $t$ statistik sebesar 5,924. nilai tersebut lebih besar dari t Tabel $(1,960)$ atau $\mathrm{p}$ $\leq 0,05 \%$. Sehingga Citra pantai Pandawa berpengaruh positif signifikan terhadap Keputusan Berkunjung wisatawan. Berdasarkan hasil dari observasi ditemukan bahwa wisatawan tertarik untuk berkunjung ke pantai Pandawa karena citra pantai Pandawa sebagai salah satu pantai terindah yang ada di Bali. Dari hasil tersebut menunjukkan bahwa hipotesis ketiga penelitian ini diterima. Pernyataan diatas diperkuat oleh hasil penelitian yang dilakukan oleh Baseer Ali Durrani, Danish Iqbal Godil, Mirza Uzair Baig dan Sana Sajid (2015), penelitian ini menunjukkan bahwa perilaku pembelian remaja berkorelasi dan dipengaruhi oleh iklan, brand loyalty dan brand image. Selanjutnya bahwa beberapa remaja memiliki perilaku pembelian tergantung pada brand loyalty, iklan dan brand image. Berkaitan dengan hipotesis ketiga dari maka dapat dikatakan bahwa citra positif dari pantai Pandawa yang melekat di benak masyarakat akan membuatnya lebih menarik untuk dikunjungi dibanding dengan destinasi lainnya. 


\section{Pengujian Citra Sebagai Intervening Variable dalam hubungan Promosi Media Sosial Terhadap Keputusan Berkunjung}

Pada hubungan Promosi Media Sosial dengan Keputusan Berkunjung terdapat dugaan bahwa variabel citra sebagai variabel intervening / penghubung. Direct Effect (pengaruh langsung) dari Promosi Media Sosial terhadap Keputusan Berkunjung sebesar 0,207. Pengujian terhadap pengaruh mediasi antar variabel intervening dengan variabel dependent yaitu pengaruh antara Promosi Media Sosial (X) terhadap variabel Keputusan Berkunjung (Y2) yang melalui intervening Citra (Y1) dilakukan dengan perhitungan rumus Sobel. Hasil perkalian dari Promosi Media Sosial (X) terhadap citra (Y1) dengan citra (Y1) terhadap keputusan berkunjung (Y2) menghasilkan standard error tidak langsung promosi media sosial (X) terhadap keputusan berkunjung (Y2), diperoleh hasil 0,0589 . Nilai t sebesar 4,855 lebih besar dari 1,96 dengan demikian dapat dikatakan bahwa parameter mediasi tersebut positif signifikan. Berdasarkan hasil perhitungan diatas dapat ditarik kesimpulan bahwa pengaruh tidak langsung dari variabel promosi media sosial $(\mathrm{X})$ terhadap keputusan berkunjung (Y2) melalui citra (Y1) dapat diterima. Keindahan dan keunikan dari Pantai Pandawa yang dipromosikan di media sosial Facebook, Twittter dan Instagram membuat wisatawan tertarik dan yakin untuk berkunjung karena citra positif Pantai Pandawa yang sudah melekat kuat di benak masyarakat.

\section{SIMPULAN}

Promosi media sosial (X) memiliki pengaruh secara langsung terhadap citra (Y1) karena memiliki nilai probabilitas $(0,554) \leq$ 0,05 yang berarti ada pengaruh positif yang signifikan. Berdasarkan hasil observasi yang dilakukan, ditemukan bahwa Fenomena menarik yang terjadi saat ini, wisatawan sendirilah yang lebih gencar mempromosikan objek wisata pantai Pandawa melalui media sosial. Hal ini tidak terlepas dari budaya selfie yang melekat di masyarakat. Semakin banyak foto atau video beserta ulasan positif tentang keindahan dan keunikan pemandangan tebing pantai serta berbagai atraksi wisata yang ada di pantai Pandawa maka akan semakin meningkatkan citra pantai Pandawa sebagai objek wisata unggulan kepada dunia.
Promosi media sosial (X) memiliki pengaruh yang positif terhadap keputusan berkunjung (Y2) karena memiliki nilai probabilitas $(0,207) \leq 0,05$ yang berarti ada pengaruh positif. Berdasarkan hasil observasi, ditemukan bahwa dengan melihat foto atau video beserta ulasan positif tentang keindahan dan keunikan pemandangan tebing pantai serta berbagai atraksi wisata pantai Pandawa di media sosial maka akan menarik minat wisatawan untuk berkunjung dan merasakan pengalamannya secara langsung. Citra (Y1) memiliki pengaruh positif signifikan terhadap keputusan berkunjung (Y2) karena memiliki nilai probabilitas $(0,516) \leq 0,05$ yang berarti ada pengaruh positif yang signifikan. Berdasarkan hasil dari observasi ditemukan bahwa wisatawan tertarik untuk berkunjung ke pantai Pandawa karena percaya pada citra pantai Pandawa sebagai salah satu pantai terindah dan unik di Bali yang terkenal akan pemandangan tebing pantai yang indah, pantai yang bersih dan banyak atraksi wisata di dalamnya. 


\section{Kepustakaan}

Akdon, Riduwan. 2011. Rumus dan Data dalam Aplikasi Statistika. Bandung: Alfabeta.

Ali, Baseer Durrani., Iqbal, Danish Godil., Uzair, Mirza Baig., Sajid, Sana. 2015. Impact Of Brand Image On Buying Behaviour Among Teenagers. European Scientific Journal February 2015 edition vol.11.

Ferdinand, Augusty. 2014. Metode Penelitian Manajemen. Semarang: Badan Penerbit Universitas Diponegoro.

Ghozali, Imam. 2013. Aplikasi Analisis Multivariate dengan Program IBM SPSS 21 Update PLS Regresi. Semarang : Badan Penerbit Universitas Diponegoro.

Guzel, Gonca Sahin dan Sengün, Gunce. 2015. The Effects of Social Media on Tourism Marketing: A Study among University Students. Management and Administrative Sciences Review Vol. 4.

Jaya, I Gede Nyoman Mindra dan I Made Sumertajaya. 2008. Pemodelan Persamaan Struktural Dengan Partial Least Square. E-Journal On-line.
Margono. 2004. Metodologi Penelitian Pendidikan. Jakarta : Rineka Cipta

Negara, I. Made Kusuma, and Putu Agus Wikanatha Sagita. "KAPABILITAS PRAKTIS DOMAIN PERJALANAN WISATA BALI: APLIKASI PERJALANAN WISATA BERBASIS PONSEL CERDAS". Jurnal IPTA 6.1 (2018): 77-83.

Suardana, I. Wayan. "Analisis kebijakan Pengembangan Pariwisata (Intervensi Melalui Kebijakan Pariwisata Berkelanjutan di Bali)." (2016).

Taprial, Varinder \& Priya Kanwar. 2012. Understanding Social Media. London: Ventus Publishing ApS.

Wenats, Eka, dkk. 2012. Integrated Marketing Communications : Success Story. Jakarta : PT.Gramedia Pustaka Utama.

Živković, Radmila., Gajić, Jelena., Brdar, Ivana. 2014. The Impact Of Social Media On Tourism. Singidunum University, Belgrade, Serbia. 